\title{
Primary Sjogren's Syndrome Presenting with Renal Tubular Acidosis and Central Pontine Myelinolysis: A Case Report
}

\author{
Renal Tübüler Asidoz ve Santral Pontin Miyelinolizis ile Seyreden Primer Sjogren Sendromu: \\ Olgu Sunumu
}

\author{
Sui RUBO, ${ }^{1}$ Lei ZHANG ${ }^{2}$ \\ ${ }^{1}$ Department of Neurology, First Affiliated Hospital of Liaoning Medical College, China \\ ${ }^{2}$ Department of Nursing, School of Nursing of Liaoning Medical College, China
}

In this case report, we present a-75-year-old female case of primary Sjogren's syndrome (pSS) with distal renal tubular acidosis (RTA) as revealed by severe hypokalemia along with normal anion gap metabolic acidosis and abnormally acidified urine. The patient had a brain stem lesion as confirmed by quadriplegia, hypersomnia, and dysphagia. Laboratory tests revealed that the anti-Ro/SSA and anti-La/SSB antibodies were positive. Magnetic resonance imaging of the brain showed a hyperintense signal at $T_{1}$ and $T_{2}$ in the mid-pons, a typical characteristic of central pontine myelinolysis.

Key words: Central pontine myelinolysis, hypokalemia; primary Sjogren's syndrome; quadriplegia; renal tubular acidosis.

Primary Sjogren's syndrome (pSS) is an autoimmune disease in which the immune system targets moistureproducing glands and causes dryness in the mouth and eyes. The incidence rate of pSS in China is $0.33-0.77 \%{ }^{[1]}$ The most common symptoms in pSS patients are dry mouth and dry eyes. In contrast, clinical manifestations that primarily present as the coexistence of distal renal tubular acidosis and central pontine myelinolysis (CPM) are very rare in pSS. Herein, we report a case of pSS in a woman with these rare manifestations, and to our knowledge, seldom have similar cases been described in the literature.
Bu olgu sunumunda şiddetli hipokaleminin ortaya çıkardığı distal renal tübüler asidoz (RTA) ve normal anyon boşluk metabolik asidozu ve anormal düzeyde asitleşmiş idrar ile birlikte seyreden primer Sjogren sendromlu (pSS) 75 yaşındaki bir kadın olgu sunuldu. Hastada kuadripleji, hipersomnia ve disfaji ile doğrulanmış beyinsapı lezyonu mevcuttu. Laboratuvar testlerinde anti-Ro/SS-A ve anti-La/SS-B antikorları pozitifti. Manyetik rezonans görüntüleme ile yapılan beyin taramasında, santral pontin miyelinolizisin tipik özelliği olan orta ponlarda $T_{1}$ ve $T_{2}$ 'de hiperintens sinyal görüldü.

Anahtar sözcükler: Santral pontin miyelinolizis; hipokalemi; primer Sjogren sendromu; kuadripleji; renal tübüler asidoz.

\section{CASE REPORT}

A 75-year-old female was admitted to our hospital with a 24-hour history of rapid and progressive weakness in all four limbs. She was diagnosed as having cerebrovascular disease at other hospital and had a past history of hypertension. Significantly, she had a four-year history of dry mouth and dry eye for but no preceding history of fever, rash, or arthralgia. The patient presented with typical symptoms of lockedin syndrome as she could not move, swallow, or communicate verbally due to complete paralysis of 
nearly all voluntary muscles in her body except for the eyes. The quadriplegia worsened rapidly and reached its highest extent on the second day after admission. Physical examinations revealed a blood pressure of 140/95 $\mathrm{mmHg}$, and a neurological examination showed that the patient was somnolent. Furthermore, her cranial nerves showed bilateral facial palsy. An evaluation of the patient's motor system identified grade 2 muscle power in both the upper and lower limbs with bilateral positive pathological reflex. Immunology investigations revealed that the serum titers of anti-Ro/SSA and anti-La/SSB antibodies, which are generally accepted as specific antibodies of pSS, were high. The test for antinuclear antibodies (ANA) was positive, but the results for anti-doublestranded deoxyribonucleic acid (anti-dsDNA), anti$\mathrm{La} / \mathrm{SSB}$, anti-Smith (anti-Sm), anti-ribonucleoprotein (anti-RNP), anti-topoisomerase I (anti-Scl-70), and anti-Jo-1 antibodies were negative. The tests for antineutrophilic cytoplasmic antibodies (ANCA), Raf antibody, and cryoglobulin were also negative. Other laboratory investigations at the time of admission showed the following: a potassium level of $1.4 \mathrm{mmol} / \mathrm{L}$ (3.6-5.0), an anion gap of $8.7 \mathrm{mmol} / \mathrm{L}$ (range; 8-16), and a $\mathrm{pH}$ of 7.300 (range; 7.350-7.450). As for the urine analysis, the results showed $1+$ albuminuria, $3+$ occult blood, and a urine $\mathrm{pH}$ of 6 . In addition, the 5 -minute Schirmer test yielded values of $2.28 \mathrm{~mm}$ in the patient's right eye and $2.42 \mathrm{~mm}$ in the left eye, and the salivary flow rate test produced a level of $1.00 \mathrm{~mL} / 15 \mathrm{~min}$. Although a computed tomography (CT) scan of the brain, electroencephalography (EEG), and cerebrospinal fluid (CSF) analysis were normal, a brain magnetic resonance imaging $(\mathrm{MRI})$ showed $\mathrm{T}_{1}$ and $\mathrm{T}_{2}$ signal hyperintensity in the pons (Figure 1 ). After the diagnosis of pSS was established, the patient was treated with prednisolone and potassium. Several days later, the patient's conscious level and cranial muscle power had improved, though the serum potassium was still at a low level. Two weeks later, the hypokalemia and acid-base disorder were corrected, and her neurological examination was normal apart from minimal truncal ataxia. A brain MRI repeated after one month showed normal findings (Figure 2).

Since being discharged from the hospital, the patient has been on steroid and cyclophosphamide therapy. She has been followed up regularly, and her condition has remained stable.

\section{DISCUSSION}

Primary Sjogren's syndrome is a chronic autoimmune disease characterized by destructive lymphocyte infiltration of the salivary and lacrimal glands resulting in dry eyes and dry mouth. Despite extensive studies of the underlying causes of pSS, the pathogenesis remains obscure. Diagnosis of pSS according to the current American- European Consensus Group (AECG) criteria $^{[2]}$ requires at least four of the following six items: subjective xerophthalmia, subjective xerostomia, an objective test for xerophthalmia, objective evidence of salivary gland dysfunction, the presence of either anti-Ro/SSA or anti-La/SSB antibodies, and histopathological criteria for pSS on a minor salivary gland biopsy. One of the four criteria must be either serologically or histopathologically positive. In our case, the history of subjective xerophthalmia, subjective xerostomia, and positive anti-SS-A(Ro) and
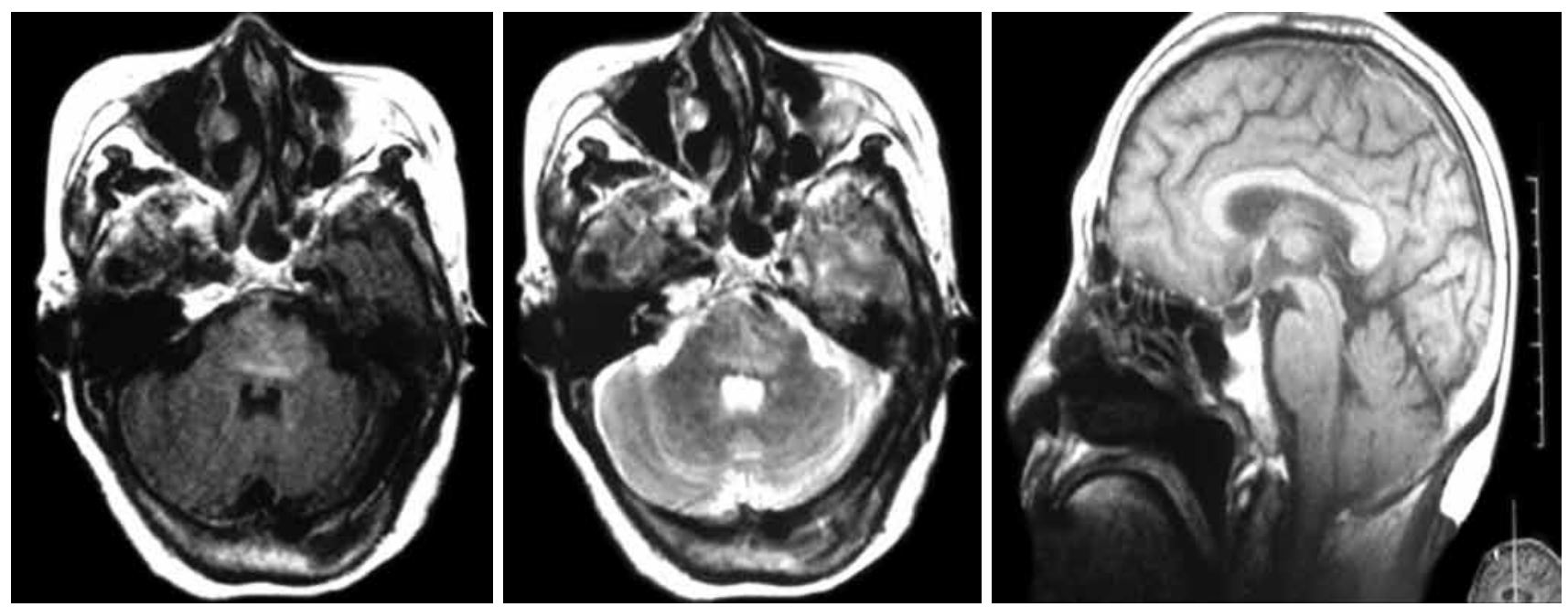

Figure 1. Brain magnetic resonance imaging of our 75 -year-old patient revealing the hyperintense signal on $\mathrm{T}_{1}$ and $\mathrm{T}_{2}$ in the pons. 

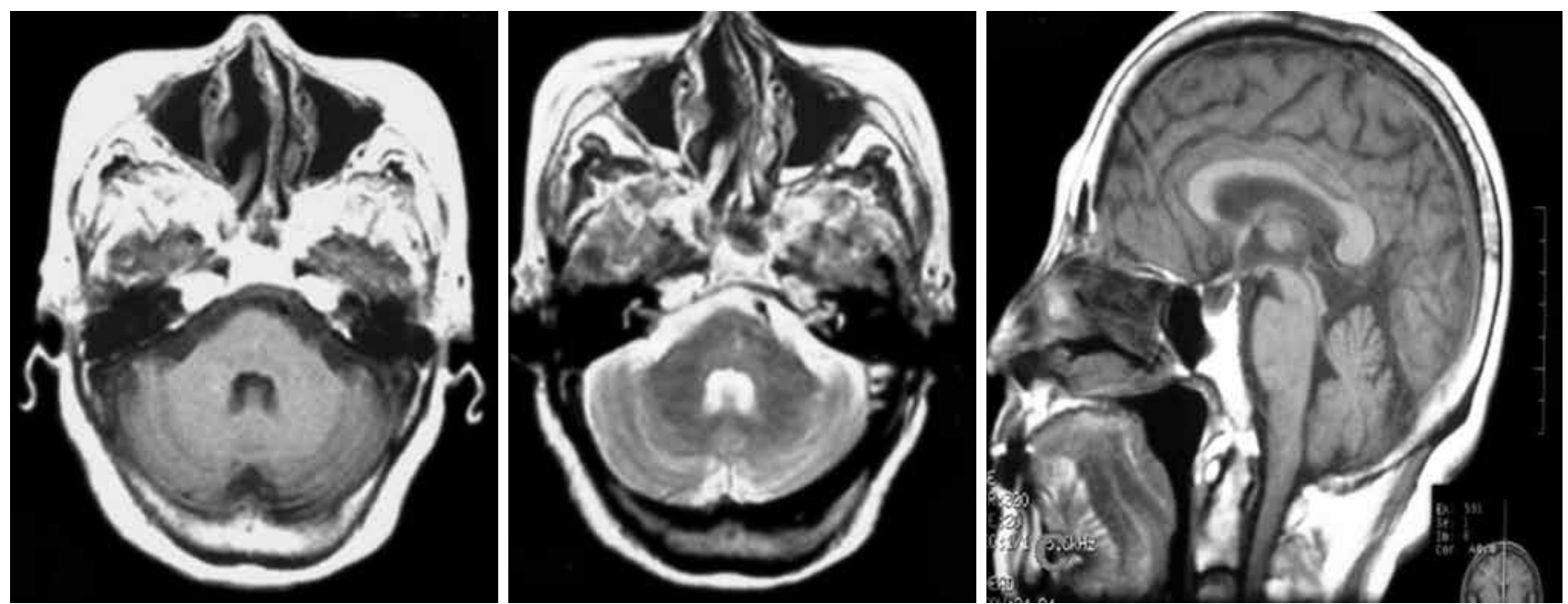

Figure 2. Brain magnetic resonance imaging repeated one month later of our 75 -year-old patient revealing the normal signal on $\mathrm{T}_{1}$ and $\mathrm{T}_{2}$ in the pons.

anti-SS-B(La) along with the results of the 5-minute Schirmer test and salivary flow rate supported the clinical diagnosis of pSS. Treatment for this disease usually is comprised of asymptomatic approach in milder cases, whereas cyclophosphamide and steroids or other immunosuppressants (chlorambucil or azathioprine) are required in cases with progressive symptoms leading to neurological impairment.

Polyneuropathy or mononeuropathy are the most common neurological manifestations in pSS, with central nervous system (CNS) involvement being less common. Central nervous system disease in pSS may include focal brain lesions, which may present as a stroke-like episode or appear more gradually. Optic neuritis, focal paresthesia, and brain stem syndromes like CPM are rare features of pSS. ${ }^{[3]}$ In this case, the patient's confusion and changes in consciousness level could not have been caused by hypokalemia since it only reduces muscle power in the limbs; however, in rare cases, this condition has been known to influence the cranial muscle by hindering the ability to swallow and verbally communication. The neurological symptoms observed in our patient were mainly due to CPM. As for the observed weakness of the four limbs, allowing for the coexistence of hypokalemia and the positive pathological reflex, we were able to presume that both the hypokalemia and CPM contributed to the quadriplegia. Central pontine myelinolysis has been associated with severe liver disease, alcoholism, sepsis, and rapid correction of chronic hyponatremia. However, CPM, a distinct neurological syndrome that is a manifestation of pSS, has rarely been reported. Recently, a report showed that one patient with CPM experienced considerable improvement by intravenous immunoglobulin therapy, indicating that the immune mechanism is involved in CPM. ${ }^{[4]}$ The clinical features of CPM include confusion and a change in consciousness level with an early progression to a comatose state. Quadriplegia, locked-in syndrome, and dysarthria, all of which were seen in our patient, can also occur. Central pontine myelinolysis on MRI is characteristically a symmetrical lesion in the white matter area of the ventral and central basal pons that is hyperintense on $\mathrm{T}_{2}$-weighted images. Generally, the management of CPM is supportive. Our patient responded to a combination of immunosuppressive therapy combined with pulse methyprednisolone and pulse cyclophosphamide.

Renal damage in pSS is common. A reduction in urinary concentrating capacity was the most common defect, and this was observed in $20 \%$ of cases in a study by Baburaj and Khanna. ${ }^{[5]}$ Other renal defects include a reduction in creatinine clearance, distal RTA, and nephrotic syndrome. Apart from systemic lupus erythematosus (SLE), most of the renal damage associated with pSS involves renal interstitial lesions. Glomerular damage is infrequent and mild. Renal tubular acidosis, especially type 1 which accounts for $91.7 \%$ of all types of RTA in pSS, ${ }^{[6]}$ is the main cause of hypokalemia along with normal anion gap metabolic acidosis. The characteristics of hypokalemia in our patient were consistent with the diagnosis of distal RTA. Of the different types of RTA associated with hypokalemia, distal RTA may be due to a defect in proximal tubular reabsorption 
found in the bicarbonate ion $\left(\mathrm{HCO}_{3}\right)$ in type $2 \mathrm{RTA}$ or a defect involving impaired distal tubular $\mathrm{H}^{+}$ secretion in $\mathrm{H}^{+}-\mathrm{ATPase} / \mathrm{H}^{+} \mathrm{K}^{+}$ATPase (type $1 \mathrm{RTA}$ ). Hypokalemia, although common in the two types of RTA, is severe and symptomatic in type 1 RTA. The gold standard that is used to distinguish between the two types of RTS involves measuring the level of fractional $\mathrm{HCO}_{3}$ excretion, which is typically $>20 \%$ in type $2 \mathrm{RTA}^{\left[{ }^{[7]}\right.}$ Treatment of distal RTA involves the oral intake of sodium bicarbonate along with potassium supplementation as a citrate in order to keep the serum $\mathrm{K}^{+}$levels normal and serum $\mathrm{HCO}_{3}$ levels at $>18 \mathrm{meq} / \mathrm{L} .{ }^{[8]}$

In conclusion, patients who potentially have pSS might be easily by overlooked by doctors because of the many non-specific symptoms of this disease. This case suggests that clinicians would benefit from increasing their knowledge of pSS, especially when it presents as RTA and/or CPM, in order to avoid a delay in diagnosis.

\section{Declaration of conflicting interests}

The authors declared no conflicts of interest with respect to the authorship and/or publication of this article.

\section{Funding}

The authors received no financial support for the research and/or authorship of this article.

\section{REFERENCES}

1. Xiang YJ, Dai SM. Prevalence of rheumatic diseases and disability in China. Rheumatol Int 2009;29:481-90. doi: 10.1007/s00296-008-0809-z.

2. Vitali C, Bombardieri S, Jonsson R, Moutsopoulos HM, Alexander EL, Carsons SE, et al. Classification criteria for Sjögren's syndrome: a revised version of the European criteria proposed by the American-European Consensus Group. Ann Rheum Dis 2002;61:554-8.

3. Yoon KH, Fong KY, Koh DR, Suri R. Central pontine myelinolysis-a rare manifestation of CNS Sjogren's syndrome. Lupus 2000;9:471-3.

4. Deleu D, Salim K, Mesraoua B, El Siddig A, Al Hail $\mathrm{H}$, Hanssens Y. "Man-in-the-barrel" syndrome as delayed manifestation of extrapontine and central pontine myelinolysis: beneficial effect of intravenous immunoglobulin. J Neurol Sci 2005;237:103-6.

5. Baburaj P, Khanna L. Secondary Sjogren's syndrome and scleroderma presenting as renal tubular acidosis. J Assoc Physicians India 2007;55:78-9.

6. Lin DF, Yan SM, Zhao Y, Zhang W, Li MT, Zeng XF, et al. Clinical and prognostic characteristics of 573 cases of primary Sjögren's syndrome. Chin Med J (Engl) 2010;123:3252-7.

7. Lerma EV, Berns JS, Nissenson AR, editors. Current diagnosis \& treatment: nephrology \& hypertension. New York: McGraw Hill Companies; 2009.

8. Bossini N, Savoldi S, Franceschini F, Mombelloni S, Baronio M, Cavazzana I, et al. Clinical and morphological features of kidney involvement in primary Sjögren's syndrome. Nephrol Dial Transplant 2001;16:2328-36. 